\title{
The role of three-dimensional ultrasound in the differential diagnosis of omphalocele and gastroschisis
}

\section{Omfalosel ve gastroşizis ayırıcı tanısında üç boyutlu ultrasonografinin rolü}

\author{
Kahraman Ülker, İsmail Temur, Mehmet Karaca, İslim Volkan, Mustafa Ersöz, Abdülaziz Gül \\ Kafkas University School of Medicine, Obstetrics and Gynecology Department, Kars, Türkiye
}

\begin{abstract}
Gastroschisis and omphalocele are the two of the most common malformations of the anterior abdominal wall that both of them associated with high morbidity and mortality. Sometimes the diagnosis and the realization of the situations by physicians and the parents are difficult. Herein, one omphalocele and one gastroschisis cases were presented with the two-dimensional and threedimensional ultrasonographic diagnostic features. The two entities and the role of three-dimensional ultrasound in diagnosis and the clinical management of the situations are discussed in the view of medical literature. The three-dimensional ultrasound helps in the diagnosis and detection of the severity of the omphalocele and the gastroschisis. J Clin Exp Invest 2011; 2(1): 106-109
\end{abstract}

Key words: Three-dimensional imaging, omphalocele, gastroschises, birth defects

\section{ÖZET}

Gasroşizis ve omfalosel karın ön duvarının en sık malformasyonlarındandır ve her ikisi de yüksek morbidite ve mortalite ile birliktedir. Bazen bu durumların tanısı hekimler için zor olmakta ve aile de farkına varamamaktadır. Bu makalede bir omfalosel ve bir gastroşizis vakasının iki ve üç boyutlu ultasonografik tanısal özellikleri sunulmuştur. Her iki durum ve bu durumların tanı ve tedavisinde üç boyutlu ultrasonografinin yeri ve klinik yönetimi tıbbi literatür ışığında tartışılmıştır. Üç boyutlu ultrasonografi omfalosel ve gastroşizisin tanı ve ağırlığını belirlemede yardımcıdır. Klin Deney Ar Derg 2011; 2(1): 106-109

Anahtar kelimeler: Üç boyutlu görüntüleme, omfalosel, gastroşizis, doğumsal defektler

\section{INTRODUCTION}

Gastroschisis and omphalocele are the two of the most common malformations of the anterior abdominal wall, both associated with high morbidity and mortality. The combined incidence of the omphalocele and the gastroschisis is 1 in 2.000 births. Mesodermal failure to replace the body stalk results in the abdominal wall defects. Enlargement of the diameter of the umbilical ring results from the embryonic dysplasia, decreased apoptotic cell death, and inadequate mesodermal development. $^{1-2}$

Abdominal wall defects can generally be diagnosed by using in utero-ultrasonography (US) ${ }^{3}$, ${ }^{4}$, however the diagnostic accuracy and the quality vary between countries ${ }^{5}$ In the report we aim to describe the two cases that we identified with the aid of three-dimensional ultrasound (3D US). Before the publication due to the World Medical Association Declaration of Helsinki, informed consent of the woman after hiding her identity was obtained.

\section{CASE 1}

A 22-year-old woman having her first pregnancy, at the 16th week was referred to our centre with the diagnosis of fetal abdominal mass. All ultrasound

Yazışma Adresi /Correspondence: Dr. Kahraman Ülker,

Kafkas Üniversitesi Tıp Fakültesi Kadın Hastalıkları ve Doğum AD, Kars, Türkiye E-mail: kahramanulker@hotmail.com

Geliş Tarihi / Received: 25.07.2010, Kabul Tarihi / Accepted: 10.08.2010

Copyright (C) Klinik ve Deneysel Araştırmalar Dergisi 2011, Her hakkı saklıdır / All rights reserved 
examinations were performed using a threedimensional (3D) ultrasound equipment (Voluson 730 Pro; General Electric-Kretztechnik, Zipf, Austria) and a motorized curved array transducer (2-5 MHz). In the two-dimensional (2D) US the protruding $22.9 \times 22.0 \mathrm{~mm}$ abdominal mass was seen. The 2D US gave the image of a separate mass just above the umbilical cord insertion site (Figure 1). By using Doppler US and 3D US, an omphalocele including the liver was identified (Figure 2). Detailed US for possible associated malformations could not find any structural defects. The family did not want to take part in any invasive investigation for a karyotyping. The woman was referred to a tertiary centre with the expertise facilities of obstetrics, medical and surgical pediatrics and anesthesia. At the time of this writing, she is at the $34^{\text {th }}$ week of the pregnancy.

\section{CASE 2}

A 26-year-old woman with a history of previous cesarean delivery and a spontaneous abortion came for routine antenatal visit for her third pregnancy at the 31st week of her pregnancy. She was living in a neighbor city and having her antenatal visits routinely beginning from the first trimester.

We performed all ultrasound examinations using a 3-dimensional (3D) ultrasound equipment (Voluson 730 Pro; General Electric-Kretztechnik, Zipf, Austria) and a motorized curved array transducer (2-5 MHz). In the 2D US the familiar image of gastroschisis was easily identified. Detailed US for possible associated malformations could not find any structural defect. With the aid of the 3D ultrasound demonstration of the entity (Figure 3), the family understood the severity of the condition. The woman was referred to a tertiary centre with the expertise facilities of obstetrics, medical and surgical pediatrics and anesthesia. At the 38th week, she was delivered with cesarean section. The neonate had two operations in the

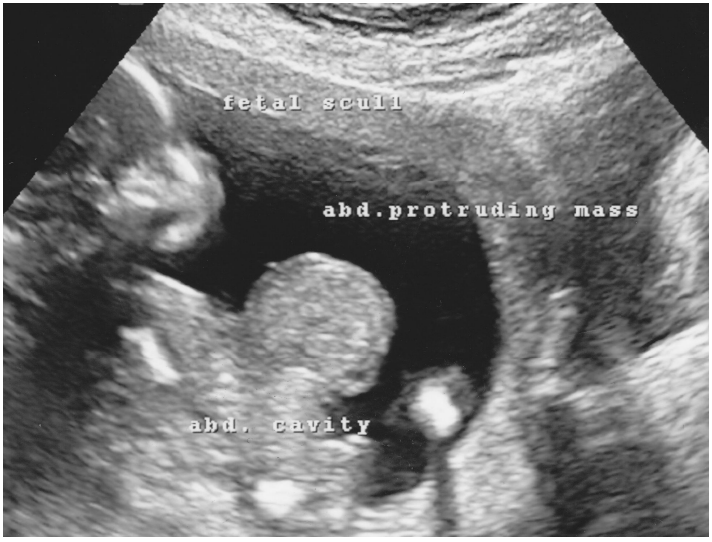

Figure 1. Two-dimensional image of the omphalocele

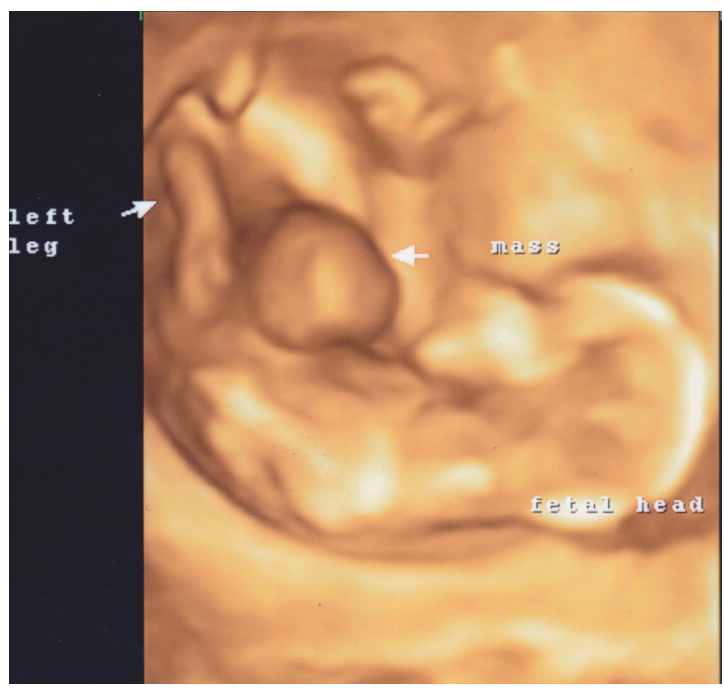

Figure 2. Three-dimensional image of the fetal omphalocele, note the fetus "like holding a ball".

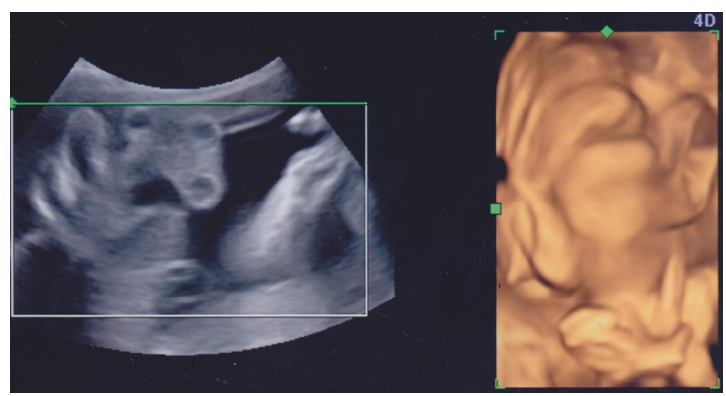

Figure 3. Two and three-dimensional image of the gastroschisis, note the dilatations of the intestines. postnatal 45 days, however could not survive. 


\section{DISCUSSION}

Central fusion failure at the umbilical ring in babies with omphalocele due to the defective mesodermal growth causes incomplete closure of the abdominal wall and the persistence of the herniation of the midgut. The translucent sac, which is composed of the amnion, Wharton jelly, and the peritoneum, contains the abdominal viscera. The radiation of the umbilical vessels onto the sac wall is seen. The extruded midgut accompanied with the liver, spleen, and the ovaries or the testes in $50 \%$ of the cases. ${ }^{1,2}$

Gastroschisis results from: 1. The dysplastic abdominal wall rupture caused by the increased abdominal pressure resulted by the defective mesenchymal development at the junction of the body stalk and abdominal wall, 2 . The localized weakness and the subsequent rupture may be caused by abnormal involution of the right umbilical vein or a vascular accident involving the omphalomesenteric artery. In prenatal ultrasonographic examination, a ruptured small omphalocele, absorption of the sac, and a growth of skin between the resultant opening and the umbilical cord has been chronicled. ${ }^{1,2}$

Babies with omphalocele frequently have other clinical problems, such as congenital heart disease, cleft palate, musculoskeletal abnormalities, and dental malocclusion. The incidence of associated chromosomal abnormalities is $10-40 \%$. These include trisomies $12,13,15,18$, and $21 .^{3,6-10}$

Genetic abnormalities rarely occur in babies with gastroschisis, however these infants may have malabsorption and intestinal motility disorders, including gastro-esophageal reflux disease and the Hirschsprung's disease., ${ }^{3,11}$

The survival of the gastroschisis and omphalocele cases has increased from $60 \%$ during the 1960 s to more than $90 \%$ currently. The parenteral nutritional, surgical and the anesthetic management techniques are improved. However, the wound closure difficulties and the gastrointestinal dysfunctions are still the cause of the long-term morbidities for gastroschisis. ${ }^{1,11}$

Elevation of the maternal serum alpha-feto protein levels is associated with the abdominal wall defects, although the levels are greater in the gastroschisis than in the omphalocele. Acetyl cholinesterase and pseudo cholinesterase rise may help to differentiate the sipina bifida from the rise of the alpha-feto protein observed in abdominal wall defects.

Antenatal ultrasound may demonstrate the entities with the co-existing associated structural defects. Generally, the detection and the differential diagnosis ratios of the two entities are high but isolated cases may be missed. ${ }^{3,5,11-13}$ In cases with difficulty to identify the exact pathology and to demonstrate the co-existing pathologies, the 3D ultrasound may be helpful. Besides its help as a diagnostic tool, the 3D ultrasound may help the family to understand and realize the situation. ${ }^{14}$ The decision process, perception of the situation and its importance, genetic counselling, future planning and the place of the management will be affected by the thorough comprehension of the family. ${ }^{15}$ We believe that in the near future, demonstration of the structural anomalies to the family will be an obligation before offering termination of the pregnancy.

Conflict of interest: The authors declared no conflicts of interest.

\section{REFERENCES}

1. Stone P. Gastrointestinal Abnormalities. In: James DK, Steer PJ, Weiner CP, Gonik B, ed. High Risk Pregnancy Management Options. 2nd ed. London: W.B.Saunders, 1999; 443-446.

2. Emanuel PG, Garcia GI, Angtuaco TL. Prenatal detection of anterior abdominal wall defects with US. Radiographics. 1995; 15:517-530.

3. Richmond S, Atkins J. A population-based study of the prenatal diagnosis of congenital malformation over 16 years. BJOG 2005; 112:1349-1357. 
4. Hertzberg BS, Kliewer MA, Bowie JD. Sonography of the fetal gastrointestinal system. In: Fleischer AC, Manning FA, Jeanty P, Romero R, ed. Sonograhpy in Obstetrics and Gynecology Principles and Practice. $5^{\text {th }}$ ed. London: Appleton and Lange, 1996; 411-431.

5. Garne E, Loane M, Dolk $\mathrm{H}$ et al. Prenatal diagnosis of severe structural congenital malformations in Europe. Ultrasound Obstet Gynecol 2005; 25:6-11.

6. Benacerraf BR, Saltzman DH, Estroff JA, Frigoletto FD. Abnormal karyotype of fetuses with omphalocele: Prediction based on omphalocele content. Obstet Gynecol 1990; 75: 317-319.

7. Gibin C, Touch S, Broth RE, Berghella V. Abdominal wall defects and congenital heart disease. Ultrasound Obstet Gynecol 2003; 21: 334-337.

8. Mayer T, Black R, Matlak ME, Johnson DG. Gastroschisis and omphalocele. An eight-year review. Ann Surg 1980; 192:783-787.
9. Reçber D, Özen S. Trizomi 13, Patau Syndrome: Bir Olgu Sunumu (Trisomy 13), Patau Syndrome: A case report. (Turkish). Van Tip Dergisi 2005; 12:29-31.

10. Erk A, Uslu T, Kara F. Prenatal ultrasonographic diagnosis of a thanatophoric dysplasia case. Anatolian J Gynecol Obst 1999; 1:51-53.

11. Fratelli N, Papageorghiou AT, Bhide A, Sharma A, Okoye B, Thilaganathan B. Outcome of antenatally diagnosed abdominal wall defects. Ultrasound Obstet Gynecol 2007; 30:266-270.

12. Oztekin O, Oztekin D, Tinar S, Adibelli Z. Ultrasonographic diagnosis of fetal structural abnormalities in prenatal screening at 11-14 weeks. Diagn Interv Radiol 2009; 15:221-225.

13. Brun M, Maugey-Laulom B, Rauch-Chabrol F, Grignon A, Diard F. Diagnostic prenatal ultrasonography of malformations of the fetal anterior abdominal wall. [Article in French] J Radiol 1998; 79:1461-1468. 